\title{
2. Sabiedrības atjaunošanas risinājumi
}

\author{
Dina Bite
}

\section{Sabiedrības atjaunošanas aktualitāte}

Zinātniskās un teritorijas attīstības un plānošanas diskusijās jēdziens "sabiedrības atjaunošana" (angl. renewal of society) tieši šādā formulējumā netiek lietots bieži. Taču nepieciešamība pievērst uzmanību sabiedrības ilgtspējai un to apdraudošiem faktoriem pastāvējusi vienmēr, parasti strauju ekonomisku, politisku un sociālu pārmaiṇu kontekstā. Latvijā sabiedrības atjaunošanas izpratne saistīta ar demogrāfiskām izmaiñām, kas apdraud sabiedrības ilgtspēju. Negatīvs iedzīvotāju dabiskais pieaugums un migrācijas tendences valstī pēdējās desmitgadēs izraisa bažas par Latvijas sabiedrības skaitlisku un saturisku turpinājumu. Latvijā joprojām ir spēkā 1995. gada MK rīkojums par demogrāfiskās situācijas uzlabošanu, kura mērḳis ir "nodrošināt latviešu nācijas skaitlisko atjaunošanos, kā arī Latvijas iedzīvotāju kvalitatīvā sastāva (iedzīvotāju veselība, izglìtība, kultūra un tikumība) un dzīves apstākḷu uzlabošanos valstī” (MK rīkojums, 1995). Līdzās demogrāfijas speciālistu prognozēm par tautas ataudzi nereti sastopami izteicieni par "latviešu izmiršanu", kas liek meklēt risinājumus demogrāfiskās situācijas uzlabošanai, piemēram, ar bērnu piedzimšanas pabalstu paaugstināšanu stimulēt dzimstību, ar remigrācijas plāna ieviešanu veicināt ārvalstīs dzīvojošu Latvijas iedzīvotāju atgriešanos u. tml. Arī VPP EKOSOC-LV ietvaros tiek meklēti risinājumi sabiedrības ilgtspèjīgai attīstībai. Šīs nodaḷas uzdevums ir, izmantojot dažādu zinātṇu nozaru atziņas, piedāvāt risinājumus sabiedrības atjaunošanas konceptam un tā piemērošanai Latvijas apstākḷiem.

\section{Jēdziena "sabiedrības atjaunošana" interpretācijas}

Akadēmiskos literatūras avotos jēdziens "atjaunošana" (angl. renewal) visbiežāk nozīmē kāda statusa turpināšanu vai atgriešanos iepriekšējā statusā un kvalitātē, perioda pagarināšanu, kad kaut kas bijis efektīvs vai derīgs. Atjaunošana ir process, kurā kaut kas no jauna tiek padarīts par spēcīgu un funkcionējošu (Definition, 2017). Ir avoti, kur termins "atjaunošana" tiek lietots sadzīiskā diskursā, attiecinot to uz atkārtotu iestāšanos kādā domubiedru grupā, dažādu formālu statusu atjaunošanu. Ja jēdziena izpratni attiecina 
uz sabiedrību, tad orientēties tā lietojumā kḷust sarežğìtāk. Burtiska jēdziena izpratne nozīmē vēlmi atgriezt sabiedrību iepriekšèjā statusā un kvalitātē, kas būtībā nav iespējams. Tâ vairāk ir emocionāla vēlme, zināma nostalǵija pēc pagātnes, kas savukārt cieši ir saistīta ar kolektīvās identitātes meklējumiem. Kā raksta amerikāṇu sociologs Freds Deiviss (Fred Davis), nostalğija pēc pagātnes ir dziḷa sociāla emocija, sociālās atmiņas forma, kam raksturīgi izcelt patīkamo pieredzi un neņemt vērā nepatīkamo pieredzi pagātnē. Nostalợija, lai arī attiecas uz pagātni, vienmēr rodas saistībā ar tagadnes bailēm vai nemieru, kam risinājumi tiek atrasti pārveidotos pagātnes modeḷos (Davis, 1979, 12). Politologs Ivars Ījabs uzsver tieši šādu pārveidotu un idealizētu pagātnes model̦u eksistenci mūsu sabiedrībā (İjabs, 2013). Lietojot terminu "sabiedrības atjaunošana", vienmēr ir vērts pārbaudīt, vai aiz tā neslēpjas emocionāla vēlme padarìt vieglāku šodienas situāciju vai, iespējams, tā ir politiska retorika. Konstruktīva pieeja diskusijai par sabiedrības atjaunošanu nozīmē izzināt, cik lielā mērā iepriekšèjās situācijas atjaunošana ir lietderīga, kādiem mērķiem tā kalpos un kā to panākt. Britu sociologs Valters G. Rancimens (Walter Garry Runciman) uzskata, ka sabiedrības atjaunošana nozīmē nevis kopēt pagātni, bet, ņemot vērā pagātnes pieredzi, veidot, pārradīt (angl. recreate) sabiedrību tādu, lai tā varētu tikt galā ar izaicinājumiem un pielāgoties straujajām izmaiñām pasaulē (What, 2012). Šādi pagātnes pieredze netiek ne pārspīlēti uzsvērta, ne atmesta, bet noder kā racionāls izejas punkts diskusijai par sabiedrības tālāku virzību.

Sabiedrības atjaunošanas nepieciešamība izpaužas dažādās situācijās, un to nosaka atšķirīgi faktori. Latvijas gadījumā tā ir depopulācija, bet citur tā ir teritorijas pārapdzīvotība. Vispārinot var teikt, ka sabiedrības atjaunošana kḷūst aktuāla, kad notiek jebkuras nozīmīgas pārmaiņas sabiedrībā - krīzes, politisku stratēǵiju izgāšanās u. c. Dažkārt sabiedrības atjaunošanas arguments ir pārmaiņu trūkums, kam raksturīga zināma stagnācija. Atjaunošanas pamatā ir divas lietas - rīcība un zināšanas, kas abas ir svarīgas gan sistēmas izdzīvošanai, gan attīstībai (Esktedt et al., 2003). Vācu filozofs Rūdolfs Šteiners (Rudolf Steiner) raksta, ka sabiedrības atjaunošana nav nekas ārkārtējs vai kaut kas tāds, no kā jāvairās. Viņaprāt, sabiedrībā notiek nemitīgas izmaiņas, kur atjaunošana pieder pie dabiskas lietu kārtības: ““sociālais jautājums” nav kaut kas, kas pēkšņi uzrodas cilvēces evolūcijā un ko var atrisināt daži indivīdi vai valdība, un kas paliks atrisināts. Tā ir modernās civilizācijas integrāla dạ̣a un kā tāda ir jārisina ik pa laikam. Cilvēce atrodas fāzē, kur sociālas institūcijas pastāvīgi rada antisociālas tendences, kas jāpārvar ikreiz no jauna. Līdzīgi kā organisms pieredz izsalkumu pēc noteikta laika, tā arī sociālais organisms pāriet no kārtības nekārtībā. Un, tāpat kā neeksistē ēdiens, kas remdē izsalkumu pastāvīgi, nepastāv universāla sociāla panaceja." (Steiner, 1999)

Apkopojot iepriekš paustos viedokḷus, var secināt, ka sabiedrïbas atjaunošana ir dabiska un regulāra pieredze, kas īpaši aktualizējas gadījumos, kad ir apdraudēta sabiedrības pastāvēšana vai pilnvērtīga funkcionēšana. Lai 
atjaunotu sabiedrību, ir jāvienojas par atjaunošanas virzienu saskaṇā ar pagātnes pieredzi, pašreizējo situāciju un iespējamo rīcību.

\section{Sabiedrības atjaunošana sociālo teoriju perspektīvā}

Klasiska sociālās attīstības teoriju dilemma ir diskusija par to, kas ir sociālo pārmaiṇu avots - kolektīvi ierosināta pāreja no viena sociālās evolūcijas posma citā vai individuāla līmeṇa iniciatīva. Daḷa sociālās attīstības teoriju (strukturālisma teorijas, makroteorijas) sabiedrību traktē kā kopumu, sistēmu, kas piedzìvo makrolīmeņa izmaiņas un attiecīgi secīgus posmus civilizācijas vēsturē. Amerikāṇu sociologs Gerhards Lenskis (Gerhard Lenski) raksturo sabiedrību kā sistēmu, kurā nebūt ne visas tās daḷas kalpo sabiedrības veseluma veicināšanai, tomēr tajā ir jābūt pietiekamai dažādu daḷu sadarbībai, lai sabiedrība sevi varētu uzturēt (Lenski, Nolan, 2009). Strukturālistu pieejas teorētiki izmaiņas sabiedrībā redz kā "intersocietālu" izlasi, kurā ik pa laikam vienas sociokulturālas sistēmas pakḷauj citas sistēmas (Nielsen, 2004). Mūsdienās makrolīmeņa procesiem ir raksturīgi tādi atslēgvārdi kā riska sabiedrība (Zinn, 2008), postmodernā sabiedrība (Jencks, 2011), pēcpatiesības laikmets (Keyes, 2004), radikālisma un populisma atdzimšana (Muranyi, 2015).

Saskaņā ar citu sociālās attīstības pieeju pārmaiṇu virzībā tiek likts uzsvars uz kopienu un indivīda atbildību. Šādā kontekstā sociālā attīstība ir cieši saistīta ar cilvēku attīstību un vides ilgtspējīgu attīstību un tiek definēta kā process, kurā sociālās struktūras transformējas, lai nodrošinātu labus dzīves apstākḷus visiem sabiedrības locekḷiem, kā arī radītu un stiprinātu jaunas izpratnes un zināšanu formas (Striano, 2010). Sabiedrības attīstības skaidrošanā ekonomisko determinismu pēdējos gadu desmitos ir nomainījis sociālais un kultūras determinisms. Ja attīstība ir apgrūtināta (recesija, depopulācija u. tml.), ekonomiskās izaugsmes ideoloǵiju piedāvā aizstāt ar citām nostādnēm, piemēram, ar nulles izaugsmi (Daugavietis, 2014).

Pašlaik aktuālās endogēnas un neoendogēnas attīstības teoriju pārstāvji apgalvo, ka iniciatīva un spēks tikt galā ar mūsdienu izaicinājumiem (atjaunot sabiedrību) pieder indivīdam un kopienai (Neumeier, 2012; Nederveen Pieterse, 2010). Šādas idejas nav jaunas, tomēr ilgu laiku tās nav izmantotas jau minētā ekonomiskā determinisma dēḷ. Rūdolfs Šteiners jau 1919. gadā iznākušajā grāmatā rakstīja, ka "sabiedrības atjaunošanas pamatā ir brīvas kultūras aktivitātes, individuāla atbildība, brīvība realizēt savus mērķus un talantus. Vienīgais ceḷš uz atjaunošanos, patiesi veselīgu ekonomiku un taisnīgumu ir veidot brīvu telpu tam, lai indivīdu labie impulsi un centieni iznāktu virspusē" (Steiner, 1999). Arī citi autori apgalvo, ka indivīdi ir attīstības avots, ja tiek izmantots viṇu potenciāls (izglītība, attieksme, ticība, vērtības, spējas un informācija). Sociālā attīstība nozīmē arī kvalitatīvas izmaiņas sabiedrībā, kad sabiedrība kopumā ir spējīga ieviest demokrātiskus un ieḳ̣aujošus rīcības modeḷus, veicināt 
uzticēšanos, izmantot kultūrvēsturisko mantojumu, jaunās tehnoloǵijas un izplatīt zināšanas (Striano, 2010; Brink, 2010; Marshall, 2000). Atjaunot sabiedrību šādā kontekstā nozīmē radīt jaunas sociālas formas, kas iedvesmo un uztur indivīdu un kopienu spēju risināt savas problēmas (angl. healing), kā arī veicināt radošumu, kritisko domāšanu, spēju adaptēties, komunicēt un sadarboties (Institute, 2013). Šĩs idejas saistās arī ar pašlaik aktuālo sociālo inovāciju jēdzienu, kas tiek lietots sociālās attīstîbas un sociālo pārmaiṇu apzīmēšanai (Howaldt et al., 2015).

Sociālās ilgtspējas koncepcija, līdzīgi kā modernās sociālās attīstības pieejas, uzsver pozitīvus apstākḷlus kopienas iekšpusē (uzticēšanās, sadarbība, līdzdalība, radošums, sociālā iekḷaušana, veselība, drošība, kvalitatīva dzìves vide un kultūrvide) un kopienas spēju radīt šādus apstākḷus. Sociālā ilgtspēja ir tad, kad formālie un neformālie procesi, sistēmas, struktūras un attiecības aktīvi veicina šĩs paaudzes un nākamo paaudžu spēju radīt veselīgu un dzīvotspējīgu sabiedrību (kopienu). Sociāli ilgtspējīgas sabiedrības ir līdztiesīgas, atbalsta dažādību, ir savstarpēji saistītas, demokrātiskas un nodrošina labu dzīves kvalitāti (McKenzie, 2004; Dillard et al., 2009). Kopumā sociālās ilgtspējas jēdziens ietver dažādus un daudzveidīgus kritērijus gan makrolīmenī, gan mikrolīmenī (sociālais kapitāls, sociālā drošība, integrācija, dzīves kvalitāte, pilsoniskā sabiedrība, spēja risināt krīzes situācijas u. c.) (Colantonio et al., 2009; Social Progress, 2014), tomēr tos visus apvieno indivīda un kopienas kā vērtības akcentēšana. Mūsdienās vides, ekonomiskais un sociālais aspekts sabiedrības ilgtspējas nodrošināšanā tiek papildināts ar t. s. ceturto pīlāru - kultūru (Culture, 2010), uzsverot gan materiālās, gan nemateriālās kultūras nozīmi sabiedrības atjaunošanā un tādējādi sasaucoties ar R. Šteinera minētajiem trim balstiem - ekonomiku, politiku, kultūru - stabilai sabiedrībai (Usher, 2015).

Latvijā individuālas versus kolektīvas atbildības diskurss mūsdienās tiek lietots un uzturēts intensīvi. Viena no joprojām redzamām postpadomju valsts iedzīvotāju nostalğiskām vēlmēm ir, lai kāds (valsts) par viniiem rūpētos. Tai pašā laikā politiķiem un ierēdņiem ir izdevīgi popularizēt individuālu atbildību, lai notušētu neveiksmīgus politiskus lēmumus, tāpēc indivīdi tiek vainoti sociālu un acīmredzamu strukturālu problēmu gadỉjumā. Dažādu līmeņu lēmumu pieņēmēji liek cerības uz lielām investīcijām, ekonomisku izrāvienu, kas ātri atrisinātu gan ar depopulāciju saistītās problēmas, gan nevienmērīgo teritoriālo attīstîbu valstī. Neraugoties uz ekonomiskā determinisma un centralizētu politisku iniciatīvu izgāšanos nesenā vēsturē, tie joprojām bieži vien tiek uzskatīti par panaceju sabiedrības atjaunošanas mērķiem. Māris Pūķis rakstā par kultūras sociālo un ekonomisko lomu uzsver: "Latvijā kopš 90-o gadu sākuma ir dominējis maldīgs uzskats par kultūru kā patērējošu nozari, kas būtiski neietekmē ekonomiku. .. aprakstītās atziṇas teorētiskā plāksnē Latvijā ir pietiekami atzìtas, taču tās nav atradušas pietiekamu pielietojumu praktiskajā politikā un ekonomikā." (Pūķis, 2011) Tās labās prakses, kuras izveidojušās neatkarīgi no valsts 
ietekmes un atbilst sabiedrības ilgtspējas koncepcijai, kā arī demonstrē iedzīvotāju pašorganizēšanās spēju un prasmes izmantot kultūras un sociālos resursus (sadarbība, kopienas saliedēšana, jaunu ekonomisku formu radīšana), joprojām vairumā gadījumu netiek uztvertas nopietni kā sabiedrības atjaunošanas resurss.

\section{Sabiedrības atjaunošanas lietišḳie risinājumi}

Analizējot zinātnisko literatūru par sabiedrības atjaunošanu, iespējams izšķirt divas galvenās pieejas - kvantitatīvo un kvalitatīvo pieeju, kā var praktiski ietekmēt situāciju un atjaunot sabiedrības pilnvērtīgu funkcionēšanu. Kvantitatīvajai pieejai atbilst tie risinājumi, ar kuru palīdzību tiek izmainīts iedzīvotāju skaits un sastāvs, paaugstināti valstij labvēlīgi demogrāfiskie rādītāji (piemēram, pieaug dzimstība, samazinās emigrācija). Kvalitatīvai pieejai atbilst kopienas un pilsoniskās sabiedrības stiprināšana, sociālā kapitāla paaugstināšana. Detalizētāks iespējamo risinājumu dalījums dots 2.1. attēlā, kurā parādīti četri galvenie lietišksie risinājumi - telpas atjaunošana, demogrāfisko un ekonomisko instrumentu lietošana un sociālo attiecību loma sabiedrības atjaunošanā.

Runājot par telpas atjaunošanu, speciālajā literatūrā visvairāk uzmanības pievērsts tieši pilsētvides fiziskās infrastruktūras sakārtošanai un degradējušos pilsētu zonu un teritoriju funkcionalitātes atjaunošanai. Šajā procesā jāṇem vērā gan drošîbas aspekti (Musterd, Ostendorf, 2008), gan funkcionālās dažādības saglabāšana (angl. preservation) un stiprināšana, ņemot vērā ekonomiskos, ekoloǵiskos, sociālos un kultūras aspektus. Šos nosacìjumus telpas fiziskai atjaunošanai var attiecināt tiklab uz pilsētvidi, kā uz lauku teritorijām, jo plašākā nozīmē telpas atjaunošana ir vietas identitātes redzamo apliecinājumu atjaunošana vai radīšana no jauna (Hody, 2001).



2.1. attēls. Lietišḳie risinājumi sabiedrības atjaunošanai

Avots: veidojusi autore, balstoties uz zinātniskās literatūras studijām. 
Mūsdienīgie ekonomiskie risinājumi lielu uzsvaru liek uz cilvēkkapitāla paaugstināšanu, diskriminācijas mazināšanu darba tirgū, darba tirgus piedāvājuma un pieprasījuma izlīdzināšanu, mūžizglìtības veicināšanu, iedzīvotāju veselības un darbspēju saglabāšanu, kā arī sociālās iekḷaušanas veicināšanu (Social Renewal, 2007). Citi autori papildus iepriekš minētajiem rosina atbalstìt mazo un vidējo uzṇēmējdarbību, t. sk. etnisko uzṇēmējdarbību (Musterd, Ostendorf, 2008), kā arī kultūras aktivitātes, ar kurām var mainīt arī bijušās industriālās teritorijas (Mulder, 2012). Minētās aktivitātes demonstrē atkāpšanos no ekonomiskā determinisma perspektīvas, sabiedrības funkcionalitāte tiek atjaunota nevis tikai ar darbībām, kas atrautas no cilvēka, bet novērtējot ikviena indivìda resursus un potenciālo devumu sabiedrībai, paredzot vietu dažādībai un alternatīvām ekonomiskām formām.

Demogrāfiskie risinājumi ir saistīti ar tādiem jautājumiem kā imigrantu integrācija, iedzīvotāju skaita un sastāva regulēšana (Haffner, 2010), dzimstības veicināšana (Renewal, 2003), pietiekamas veselības aprūpes nodrošināšana, sabiedrības novecošanas problemātikas aktualizēšana, darba un gimenes dzīves saskaņošana, ǵimen̦u dzīves kvalitātes uzlabošana u. c. Beḷgu sociologs un demogrāfs Ron J. Lesthaeghe jau 1984. gadā uzsvēra, ka sociālajam un ekonomiskajam sektoram ik pa laikam jāpielāgojas demogrāfiskajām izmaiņām sabiedrības atjaunošanas procesā. Ja to neņem vērā, tad pastāv risks atjaunošanas problēmas reducēt tikai līdz demogrāfiskajam aspektam, kas, atsevišķi n̦emts, nedod risinājumu (Lesthaeghe, 1984). Šì atziṇa, iespējams, izskaidro arī Latvijas apstākḷos ieilgušos vājos rezultātus sabiedrības atjaunošanā.

Sociālās atjaunošanas stratēǵijas izstrādē tiek ieteikts balstîties uz pašreizējo situāciju un pieejamajiem resursiem. Piemēram, Lielbritānijas sociālās atjaunošanas stratēgijā ir šādi trīs nozīmīgākie darbības virzieni: varas un atbildības decentralizācija, savstarpēja atbalsta un mijiedarbības veicināšana makrolīmenī un mikrolīmenī, vietējo pilsoniskās sabiedrības institūciju (formālu un neformālu veidojumu) stiprināšana (Lawton et al., 2014). Individuālo vērtību, sociālo attiecību saistību ar ekonomikas attīstību aprakstijiusi filozofe Greisa Lì Bogsa (Grace Lee Boggs) (2.2. attēls).

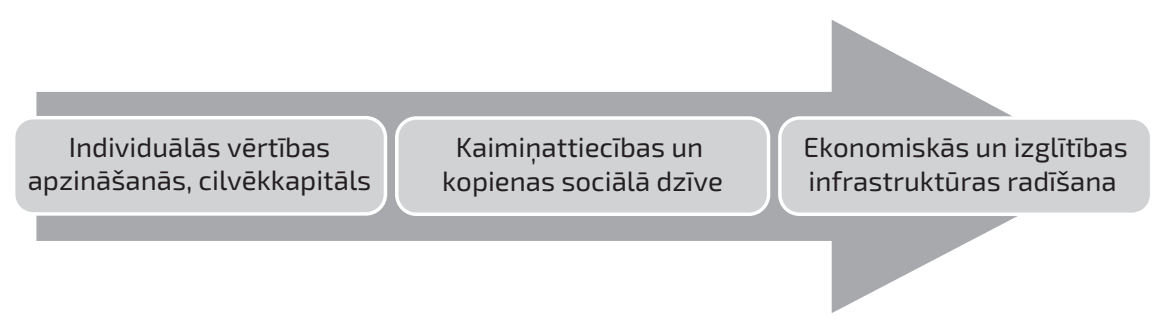

2.2. attēls. Sociālo attiecību saistība ar ekonomikas attīstību

Avots: veidojusi autore, balstoties uz Greisas LīBogsas teorētisko pieeju. 
G. L. Bogsa apgalvo, ka mūsdienu sabiedrību var atjaunot, veidojot ilgtspējīgu un uz sadarbību balstītu kopienu un kaimiņattiecības, panākot līdzsvaru starp ekstensīvu ekonomiku un intensīvu kopienas dzīvi, kā arī aizvietojot patērētājsabiedrību ar amatniecību un radošumu; viņa aicina attīstīt "horizontālu" un "no apakšas uz augšu" vērstu ekonomiku (Boggs, 2012; Chen, 2015). Tādējādi tiek akceptētas indivīdu un kopienu radošās aktivitātes dažādās dzìves jomās un veicināta sadarbība, kas rezultējas jaunās ekonomiskās formās.

Mūsdienu sabiedrības attīstības koncepcijas kā dažādu izaicinājumu risinājumu atzīst nepieciešamību pielāgoties ātri mainīgiem apstākḷiem, cilvēkkapitāla paaugstināšanu un kopienu nostiprināšanu. Ši pieeja tiek kritizēta, jo, uzsverot sociālos un kultūras aspektus, netiek pietiekami novērtēts ekonomiskais aspekts. Daḷeji tas ir saistīts ar iepriekš minēto dilemmu starp kolektīvismu un individuālismu, centralizāciju un decentralizāciju, ekonomikas determinismu un kultūras determinismu. Tāpat ir jānemem vērā fakts, ka kultūras un sociālajā dzīvē sakņotas ekonomiskās prakses ir salīdzinoši jaunas, bieži nelielas un nereti pastāv t. s. slēptajā ekonomikā, ar to saprotot gan to neformālo dabu (Raubisko, 2012), gan to neiekḷaušanu statistikā un nepietiekamu izpēti. Tāpēc būtiska ekonomikas dą̧a cieš no nepietiekamām investīcijām un ekonomiskas marginalizācijas (Creative, 2010) un šādā veidā kvalificējas kā nenovērtēts sabiedrības atjaunošanas resurss.

Attiecinot iepriekš minētos risinājumus uz Latvijas situāciju un balstoties uz Projektā veikto izpēti, var apgalvot, ka Latvijas pilsētās un novados zināmas aktivitātes notiek visos minētajos sabiedrības atjaunošanas aspektos, kaut gan ar atšķirīgu intensitāti un izplatību. Pateicoties ES finansējuma pieejamībai, pašvaldībām un citiem sociālajiem ağentiem ir iespējams atjaunot kultūrvēsturiskos objektus, attīstīt infrastruktūru. Augsta rosība vērojama kultūras vērtību saglabāšanā, radošās sociālās un ekonomiskās aktivitātēs. Pakāpeniski notiek pāreja no izteikti kvantitatīvas pieejas sabiedrības atjaunošanā uz kvalitatīvu pieeju. Par to liecina, piemēram, pašvaldību uzmanības koncentrēšana uz vietējo iedzīvotāju potenciāla izmantošanu, sadarbības tīklu un horizontālu sociālo tīklu veidošanos, kaimiņattiecību un kopienu attīstību (Kruzmetra et al., 2016; Bite, Kruzmetra, 2016). Pašlaik par nepietiekamu var uzskatīt institucionālu atbalstu sabiedrības ierosinātajām jaunajām iniciatīvām. Aktīvā sabiedrības daḷa un kopienas ir realizējušas sabiedrības atjaunošanas iniciatīvas un dažkārt šai ziṇā apsteigušas politikas veidotājus, taču tās saskaras ar sistēmiskiem ierobežojumiem, un, lai iniciatīvas attīstìtos, vitāli nepieciešams idejisks akcepts un normatīvs ietvars.

\section{Kopsavilkums}

Sabiedrības atjaunošana uzskatāma par dabisku sabiedrības attīstības procesu un nepieciešamību, kas prasa zināmu pārkārtošanos un izmaiņas ierastajās struktūrās. Sabiedrības attīstības un ilgtspējas teorijas par būtiskāko resursu 
uzskata individuālo potenciālu jeb cilvēkkapitālu, kā arī savstarpēju sadarbību un uzticēšanos kopienā, kas tālāk rada jaunas sociālas un ekonomiskas struktūras sabiedrības ilgtspējai. Sabiedrības atjaunošana ietver sintēzi no iespējamo kvantitatīvo un kvalitatīvo risinājumu klāsta, kas katrā gadījumā ir unikāls, ietverot gan pieredzi, gan pašreizējo situāciju, gan sabiedrības attīstības mērḳus. Arī demogrāfisko procesu un struktūru analīzē vienlīdz nozīmīgi ir visi ilgtspējas aspekti (vides, ekonomiskie un sociālie). Tādēl pētnieciskajam ietvaram jāieklauj gan makroprocesi, gan mikroprocesi sabiedrībā, gan kvantitatīvi, gan kvalitatīvi rādītāji. Jāṇem vērā, ka demogrāfiskos procesus ietekmē iedzīvotāju ikdienas izvēles, situācijas un problēmas.

Sabiedrības atjaunošanas risinājumos jārespektē iedzīvotāju vajadzības un jāpadara labāka viṇu ikdienas dzīve. Izvērtējot Latvijā dominējošo diskursu sabiedrības atjaunošanas aspektos, jāsecina, ka joprojām priekšplānā bieži dominē politiskas un ideoloğiskas manipulācijas un samērā konservatīvi uzskati. Aiz tiem marginālā statusā atrodas sociālās un ekonomiskās prakses, kam ir attīstības potenciāls un kam daudzās citās valstīs ierādīta būtiska loma sabiedrības un teritorijas attīstîbas stratēgijās un rīcībpolitikās. Tāpēc atbilstoši iepriekš minētajām nostādnēm ir jāstiprina iedzīvotāju rīcībspēja un atbildība. Tikai pēc tam var gaidīt pozitīvas demogrāfisko rādītāju tendences. Latvijā nepieciešamas racionālas diskusijas, reāla resursu apzināšana un novērtěšana, kā arī telpisko, ekonomisko, demogrāfisko un sabiedrības atjaunošanas aspektu lïdzsvarota izmantošana.

\section{Literatūra un avoti}

Bite, D., Kruzmetra, Z. (2016) Social Practices of Rural Population for Renewal of Society in Latvia. In: Proceedings of the International Conference "New Challenges of Economic and Business Development - 2016: Society, Innovations and Collaborative Economy". Riga: University of Latvia.

Boggs, G. L. (2012) The Next American Revolution: Sustainable Activism for the Twenty-first Century. Berkeley: University of California Press.

Brink, C. (2010) Civil Society and Social Renewal [http://www.ncl.ac.uk/executive/assets/documents/CivilSocietyandSocialRenewal.pdf (27.12.2016.)].

Chen, M. (2015) Grace Lee Boggs' Century for Social Renewal [http://america.aljazeera.com/opinions/2015/10/grace-lee-boggs-century-of-social-renewal.html (28.10.2016.)].

Colantonio, A., Dixon, T., Ganser, R., Carpenter, J., Ngombe, A. (2009) Measuring Socially Sustainable Urban Regeneration in Europe. Oxford: Oxford Institute for Sustainable Development [http://www.innovateballymun.org/sites/default/files/socialinnovation/Social\%20Sustainabilityand\%20Urban\%20Regenerationreport_0.pdf (28.10.2016.)].

Creative Rural Communities: Proposal for a Rural Cultural Strategy (2010) [http://www.ruralculture.org.uk/wp-content/uploads/2010/07/RCS_web.pdf (15.03.2017.)].

Culture: Fourth Pillar of Sustainable Development (2010) [http://www.agenda21culture.net/index.php/docman/-1/393-zzculture4pillarsden/file (12.03.2017.)].

Daugavietis, J. (2015) Amatiermāksla Latvijā: kopienas attistïba un kultūrpolitika [http://www.szf. lu.lv/fileadmin/user_upload/szf_faili/Petnieciba/promocijas_darbi/promocijas_darbs_Janis_ Daugavietis_FIN.pdf (24.02.2017.)]. 
Davis, F. (1979) Yearning for Yesterday: A Sociology of Nostalgia. New York: Free Press.

Definition of RENEWAL. An Encyclopedia Britannica Company [https://www.merriam-webster. com/dictionary/renewal (07.02.2017.)].

Dillard, J., Dujon, V., King, M. C. (2009) Introduction. In: Dillard, J., Dujon, V., King, M. C., eds. Understanding the Social Dimension of Sustainability. New York: Routledge, 1-12.

Esktedt, E., Lundin, R. A., Soderholm, A., Wirdenius, H. (2003) Neo-Industrial Organising: Renewal by Action and Knowledge Formation in a Project-intensive Economy. London: Routledge.

Haffner, J. (2010) Immigration as a Source of Renewal in Japan [http://www.policyinnovations.org/ ideas/commentary/data/000161 (13.03.2017.)].

Hody, E. (2001) Village Renewal and the Preservation of Rural Culture. Challenges, Chances, Ideas [http://www.ainova.sk/files/file/BHCD\%20praca\%20Village\%20Renewal\%20and\%20the\%20 Preservation\%20of\%20Rural\%20Culture.pdf (12.11.2016.)].

Howaldt, J., Kopp, R., Schwarz, M. (2015) On the Theory of Social Innovations: Tarde's Neglected Contribution to the Development of a Sociological Innovation Theory [http://www.ssoar.info/ ssoar/bitstream/handle/document/41963/ssoar-2015-howaldt_et_al-On_the_theory_of_social. pdf?sequence $=1$ (02.03.2017.)].

Institute for Social Renewal (2013) [http://socialrenewal.com/what-we-do/ (27.10.2016.)].

İjabs, I. (2013) Atvērto acu patriotisms [http://www.satori.lv/raksts/6456/Atverto_acu_patriotisms (27.02.2017.)].

Jencks, C. (ed.) (2011) The Post-Modern Reader. London: John Wiley \& Sons Ltd, $2^{\text {nd }}$ edition.

Keyes, R. (2004) The Post-Truth Era: Dishonesty and Deception in Contemporary Life [http://www. ralphkeyes.com/the-post-truth-era/ (02.02.2017.)].

Kruzmetra, Z., Bite, D., Kronberga, G. (2016) Cultural Environment as a Potential for Society Renewal. In: Proceedings of the International Scientific Conference "Economic science for rural development", pp. 57-64.

Latvieši izmirs vai neizmirs? Ko par to domā populāri cilvēki? (2015) [http://www.delfi.lv/izklaide/skats/cilveki/latviesi-izmirs-vai-neizmirs-ko-par-to-doma-populari-cilveki.d?id=46345261 (12.12.2016.)].

Lawton, K., Cooke, G., Pearce, N. (2014) The Conditions of Britain. Strategies for Social Renewal. Institute for Public Policy Research, London, $280 \mathrm{p}$.

Lenski, G., Nolan, P. (2009) Human Societies: An Introduction to Macrosociology. Boulder: Paradigm Publishers, $11^{\text {th }}$ edition, p. 410.

Lesthaeghe, R. J. (1984) Demographic Renewal and Problems of Social Organization [http://www. vub.ac.be/demography/wp-content/uploads/2016/02/WP-IPD-1984-4.pdf (15.03.2017.)].

Marshall, D. (2000) Renewing Cultural Studies. A Journal of Media and Culture. Vol. 6. [http:// journal.media-culture.org.au/0012/studies.php (04.01.2017.)].

McKenzie, S. (2004) Social Sustainability: Towards Some Definitions. Working Paper Series No. 27. Hawke Research Institute, University of South Australia [http://w3.unisa.edu.au/hawkeinstitute/publications/downloads/wp27.pdf (28.10.2016.)].

MK rīkojums Nr. 391, pieņemts 19.07.1995. [http://likumi.lv/ta/id/36053-par-demografiskas-situacijas-uzlabosanu (12.12.2016.)].

Mulder, A. (2012) A Place to be Proud of: Heritage and Social Inclusion in Shrinking Cities (Germany and United Kingdom). In: Martinez-Fernandez, K., Kubo, N., Noya, A., Weyman T., eds. Demographic Change and Local Development: Shrinkage, Regeneration and Social Dynamics, pp. 273-279.

Muranyi, I. (ed.) (2015) Eternal Return? The Specter of Radicalism among Young People in Europe and Hungary. Budapest: L'Harmattan, $224 \mathrm{p}$.

Musterd, S., Ostendorf, W. (2008) Integrated Urban Renewal in the Netherlands: a Critical Apraisal. Urban Research and Practice, Vol. 1, 78-92. 
Nederveen Pieterse, J. (2010) Development Theory: Deconstructions/Reconstructions. $2^{\text {nd }}$ edition. London: SAGE Publications Ltd. [http://www.tubar.com.tr/TUBAR\%20DOSYA/development\%20theory\%20-\%20jan\%20nederveen\%20pieterse.pdf (27.12.2016.)].

Neumeier, S. (2012) Why do Social Innovations in Rural Development Matter and Should They be Considered More Seriously in Rural Development Research? - Proposal for a Stronger Focus on Social Innovations in Rural Development Research. Sociologia Ruralis, 52 (1): 48-69.

Nielsen, F. (2004) The Ecological-Evolutionary Typology of Human Societies and the Evolution of Social Inequality. Sociological Theory, 22 (2): 292-314.

Pūķis, M. (2011) Kultūras mantojuma sociālā un ekonomiskā loma [http://mantojums.lv/media/ uploads/dokumenti/petijumi/pukis_kulturas_mantojums_ekosoc_loma.pdf (12.03.2017.)].

Raubisko, I. (2012) Invisible Work in the Latvian Countryside. Humanities and Social Sciences Latvia, 20 (2): 18-51.

Renewal Theory and the Stable Population Model (2003) Encyclopedia of Population [http:// www.encyclopedia.com/social-sciences/encyclopedias-almanacs-transcripts-and-maps/renewal-theory-and-stable-population-model (2017.03.03.)].

Social Progress Index (2014) [http://www.socialprogressimperative.org/data/spi\# (07.02.2017.)].

Social Renewal Operational Programme 2007-2013 (2007) The Government of the Republic of Hungary [http://pdc.ceu.hu/archive/00003634/ (12.12.2016.)].

Steiner, R. (1999) Towards Social Renewal: Rethinking the Basis of Society. London: Rudolf Steiner Press, $4^{\text {th }}$ edition, $134 \mathrm{p}$.

Striano, M. (2010) Philosophical Inquiry as a Practice for Social Development [http://www.e-publicacoes.uerj.br/index.php/childhood/article/view/20557/14883 (02.02.2017.)].

Usher, S. E. (2015) The Threefold Social Organism: An Introduction [http://www.rudolfsteinerweb. com/Threefold_Social_Order.php (12.03.2017.)].

Valsts pētījumu programma EKOSOC-LV (2014) [http://www.lza.lv/index.php?option=com_conte nt\&task $=$ view\&id $=2312 \&$ Itemid $=443(12.12 .2016)$.$] .$

What Does Social Renewal Mean to You? (2012) [https://www.youtube.com/watch?v=JHflY0O Wfo (07.02.2017.)].

Zinn, J. O. (ed.) (2008) Social Theories of Risk and Uncertainty: An Introduction. Oxford: Blackwell Publishing, $254 \mathrm{p}$. 